of Respiratory Medicine, Centre for Respiratory Research and Nottingham Respiratory Biomedical Research Unit, University of Nottingham, Nottingham, UK

Introduction Idiopathic pulmonary fibrosis (IPF) is a common, progressive interstitial lung disease. Current treatments are ineffective. Ion channels are emerging as attractive therapeutic targets and in particular, the $\mathrm{Ca}^{2+}$-activated $\mathrm{K}^{+}$channel $\mathrm{K}_{\mathrm{Ca}} 3.1$ has been shown to modulate the activity of several structural and inflammatory cells which play important roles in model diseases characterised by tissue remodelling and fibrosis. We hypothesise that $\mathrm{K}_{\mathrm{Ca}} 3$.1-dependant cell processes are a common denominator in IPF. Aims The aim of the study was to determine whether the $\mathrm{K}_{\mathrm{Ca}} 3.1$ channel is expressed in human lung derived (myo)fibroblasts, key effector cells in IPF

Methods Human lung (myo)fibroblasts derived from non-fibrotic lobectomy specimens were grown in vitro, and characterised by immunofluorescence. RT-PCR was used to examine $\mathrm{K}_{\mathrm{Ca}} 3.1 \mathrm{mRNA}$ expression. Western blot was used to confirm the presence of $\mathrm{K}_{\mathrm{Ca}} 3.1$ channel protein. Patch clamp electrophysiology was performed to demonstrate the presence of functional $\mathrm{K}_{\mathrm{Ca}} 3.1$ channels. To elicit $\mathrm{K}_{\mathrm{Ca}} 3.1$ currents the $\mathrm{K}_{\mathrm{Ca}} 3.1$ opener 1 -EBIO $(0.1 \mathrm{mM})$ was used.

Results Human lung (myo)fibroblasts, express the $\mathrm{K}_{\mathrm{Ca}} 3.1$ channel at the mRNA level. Western blot demonstrated that the $\mathrm{K}_{\mathrm{Ca}} 3.1$ protein is also present in human lung (myo)fibroblasts. (Myo)fibroblast cell lysates contained immunoreactive protein of approximately $48 \mathrm{kD}$ molecular weight, consistent with the reported size of the $\mathrm{K}_{\mathrm{Ca}} 3.1$ channel. Patch clamp electrophysiology demonstrated the presence of ion currents typical of those carried by $\mathrm{K}_{\mathrm{Ca}} 3.1$ channels. These increased in magnitude from passage two through passage seven. Overall, $\mathrm{K}_{\mathrm{Ca}} 3.1$ currents were elicited in $62 \%$ of cells tested. In those cells, baseline currents of (mean \pm SEM) $53.76 \pm 7.95 \mathrm{pA}$ at $+40 \mathrm{mV}$ increased to $1375 \pm 195.1 \mathrm{pA}$ following addition of 1 -EBIO ( $\mathrm{n}=40$ cells, $\mathrm{p}<0.0001)$, and were blocked by the selective $\mathrm{K}_{\mathrm{Ca}} 3.1$ blocker, TRAM-34 (200 nM). There was an accompanying negative shift in cell reversal potential from $-13.11 \pm 2.011$ to $-42.60 \pm 2.061$ with addition of 1 -EBIO $(\mathrm{p}<0.0001)$, which was reversed by TRAM-34.

Conclusion Human lung-derived (myo)fibroblasts express functional $\mathrm{K}_{\mathrm{Ca}} 3.1, \mathrm{~K}^{+}$channels. These findings raise the possibility that blocking the $\mathrm{K}_{\mathrm{Ca}} 3.1$ channel may inhibit pathological myo(fibroblast) function in IPF, and thus offer a novel approach to therapy.

\section{S143 SERUM MANNOSE BINDING LECTIN DEFICIENCY IS PRESENT IN PATIENTS WITH EARLY ONSET INTERSTITIAL PULMONARY FIBROSIS AND THOSE WITH AFFECTED RELATIVES SUGGESTING A GENETIC RISK FACTOR FOR DEFECTS IN THE INNATE IMMUNE SYSTEM}

doi:10.1136/thx.2010.150946.44

${ }^{1} \mathrm{~V}$ A Varney, ${ }^{1} \mathrm{~J}$ Evans, ${ }^{1} \mathrm{H}$ Parnell, ${ }^{2} \mathrm{~A}$ Nicholas, ${ }^{2} \mathrm{~B}$ Barjardeen, ${ }^{2} \mathrm{~N}$ Sumar. ${ }^{1}$ Respiratory Department, St Helier Hospital, Carshalton, Surrey, UK; ${ }^{2}$ Immunology Department St Helier Hospital, Carshalton Surrey, UK

Background Idiopathic pulmonary fibrosis (IPF) is a serious progressive lung disease with likely environmental and genetic risk factors that are thought to contribute to the disease even though their exact nature is unknown. It is increasingly recognised that siblings and close blood relatives can develop the same condition suggesting an unknown genetic predisposition.

Method We have examined the serum mannose binding lectin levels $(\mathrm{MBL})$ in healthy controls (HC), frequently exacerbating COPD, pulmonary TB \& Sarcoidosis along with IPF patients.

Results Mean serum MBL levels were not statistically different in $\mathrm{HC}, \mathrm{COPD}$ or TB using an unpaired t test. Cases with sarcoid had higher levels. Those with IPF onset at $<50$ years old and those with affected blood relatives $(\mathrm{FH})$ had significantly reduced levels compared with IPF onset $>50$ years without a family history.
Abstract S143 Table 1 shows means, SEM and $p$ values, and the per cent of each patient group with normal $>650$, moderate $100-600$ or severe deficiency levels $<100$.

Abstract S143 Table 1

\begin{tabular}{|c|c|c|c|c|c|c|c|c|}
\hline Parameter & $\begin{array}{l}\text { Mean } \\
\mathrm{MBL} \pm \text { SEM } \\
\mathrm{pg} / \mathrm{ml}\end{array}$ & $\begin{array}{l}\text { p Value } \\
\text { v's HC }\end{array}$ & $\begin{array}{l}\text { p Value } \\
\text { v's } \\
\text { IPF>50 } \\
\text { years }\end{array}$ & $\begin{array}{l}p \text { Value } \\
\text { v's } \\
\text { IPF }<50 \\
\text { years }\end{array}$ & $\begin{array}{l}\text { p Value } \\
\text { v's IPF } \\
\text { \& FH }\end{array}$ & $\begin{array}{l}\%>650 \\
\text { MBL }\end{array}$ & $\begin{array}{l}\% 100- \\
600 \\
\text { MBL }\end{array}$ & $\begin{array}{l}\%<100 \\
\text { MBL }\end{array}$ \\
\hline $\mathrm{HC} n=111$ & $1315 \pm 136$ & - & 0.48 & 0.035 & 0.01 & 53 & 32 & 15 \\
\hline $\operatorname{COPD} n=33$ & $1492 \pm 257$ & 0.58 & 0.90 & 0.05 & 0.022 & 55 & 27 & 18 \\
\hline TB $n=47$ & $1945 \pm 268$ & 0.98 & 0.24 & 0.004 & 0.004 & 72 & 11 & 17 \\
\hline $\begin{array}{l}\text { Sarcoid } \\
\mathrm{n}=38\end{array}$ & $2040 \pm 275$ & 0.02 & 0.12 & 0.002 & 0.0012 & 68 & 16 & 16 \\
\hline $\begin{array}{l}\text { IPF }>50 \\
\mathrm{n}=60\end{array}$ & $1475 \pm 203$ & 0.48 & - & 0.012 & 0.007 & 58 & 32 & 10 \\
\hline $\begin{array}{l}\mathrm{IPF}<50 \\
\mathrm{n}=19\end{array}$ & $632 \pm 213$ & 0.03 & 0.012 & - & 0.59 & 26 & 42 & 32 \\
\hline $\begin{array}{l}\text { IPF \& FH } \\
\mathrm{n}=18\end{array}$ & $688 \pm 279$ & 0.01 & 0.007 & 0.59 & - & 27 & 33 & 40 \\
\hline
\end{tabular}

Discussion Serum MBL forms part of the complement activation and innate immune system and protects the lung from infection by organisms that bind mannose sugar (eg, strep, staph, yeasts, P. Jiveci). MBL deficiency gives an opsonisation defect with reduced phagocytosis by alveolar macrophages. Blood levels are genetically determined, with UK population data showing:

- $12 \%$ severe deficiency $<100 \mathrm{pg} / \mathrm{ml}$,

- 34\% moderate deficiency 100-600 pg/ml,

- 54\% normal < $650 \mathrm{pg} / \mathrm{ml}$.

Serum levels relate to polymorphisms of the MBL2 genes. $\chi^{2}$ analysis of frequency distribution showed no differences for $\mathrm{HC}$, COPD \& IPF $>50$ years. TB\&Sarcoid had higher frequencies of normal MBL levels compared with HC ( $p=0.001$ and 0.024 respectively). IPF $<50$ \& IPF\& FH showed higher frequencies of moderate and severe deficiency compared with $\mathrm{HC}$ and all other groups ( $p=0.001$ and 0.001 respectively).

The literature shows MBL to consistently have interesting and important central roles in lung defenses via effects on complement, apoptosis and cytokines. Its observed deficiency in young IPF and those with a FH could be a genetic risk factor of relevance, explaining its early occurrence in deficiency and later occurrence in 'sufficiency', where it gives protection from insult or injury to the lung.

\section{Smoke and pollution in COPD mechanisms S144 CIGARETTE SMOKE DYSREGULATES PRO-INFLAMMATORY CYTOKINE RELEASE FROM AIRWAY EPITHELIAL CELLS AND MACROPHAGES IN RESPONSE TO HAEMOPHILUS INFLUENZAE}

doi:10.1136/thx.2010.150946.45

${ }^{1}$ E J Moisey, 'L A Borthwick, ${ }^{2} \mathrm{~J}$ Perry, ${ }^{1}$ A De Soyza, ${ }^{1}$ A J Fisher. ${ }^{1}$ Newcastle University, Newcastle upon Tyne, UK; ${ }^{2}$ Newcastle upon Tyne Hospitals NHS Trust, Newcastle upon Tyne, UK

Background Chronic obstructive pulmonary disease (COPD) is characterised by repeated viral or bacterial exacerbations which increase morbidity, mortality and accelerate lung function decline. Chronic bacterial colonisation, frequently recognised in stable COPD patients, may contribute to airway inflammation and promote disease progression. Cigarette smoke has previously been shown to alter responses to LPS via the TLR-4 receptor in cell lines. We hypothesised that cigarette smoke would suppress the innate immune responses of airway epithelial cells and macrophages to Haemophilus influenzae (HI) favouring persistence. 
Methods Primary bronchial epithelial cells (PBEC) and macrophagelike cells (THP-1) were incubated with varying concentrations of cigarette smoke extract (CSE) before stimulation with whole cell lysates of HI prepared from clinical isolates. Cell viability was assessed by flow cytometry and PBEC proliferation was analysed using an XTT assay. Pro-inflammatory cytokine release (IL-8, TNF $\alpha$, IL-1 $\beta$ ) was assessed in PBEC and PMA-differentiated THP-1 cells by ELISA.

Results CSE concentrations $\leq 10 \%$ had no significant effect on PBEC or THP-1 cell viability, however CSE concentrations $>5 \%$ inhibited PBEC proliferation $(\mathrm{p}<0.05, \mathrm{n}=9)$. PBEC demonstrated increased release of IL-8 in response to treatment with 5\% CSE and increasing doses of $\mathrm{HI}(n=3, p<0.05)$. Co-treatment with HI + CSE accentuated IL-8 release from PBEC even at CSE concentrations of $1-2.5 \%$ which had no effect alone $(p<0.05, n=6)$. TNF $\alpha$ and IL- $1 \beta$ release from PBEC were below the detection limit of the ELISA. THP-1 cells increased the release of IL-8, TNF- $\alpha$ and IL- $1 \beta$ in response to treatment with HI $(\mathrm{n}=3, \mathrm{p}<0.05)$ however CSE alone had no effect on cytokine production $(n=3, p>0.05)$. Co-treatment of THP-1 cells with HI + CSE increased IL-8 release (61\%), but reduced TNF- $\alpha$ (40\%) and IL-1 $\beta$ $(24 \%)$ release compared to treatment with $\mathrm{HI}$ alone $(\mathrm{n}=3, \mathrm{p}<0.05)$.

Conclusions CSE alters epithelial cell and macrophage responses to bacterial pathogens by promoting release of the neutrophil chemokine IL- 8 whilst at the same time suppressing TNF $\alpha$ and IL-1 $\beta$ release. This dysregulation may promote continued neutrophil inflammation in the airway whilst insufficiently clearing pathogens and could be an important mechanism in COPD.

\section{S145 THE IMPACT OF CIGARETTE SMOKE EXTRACT ON INFLAMMATORY RESPONSES AND TOLL-LIKE RECEPTOR-4 EXPRESSION IN HEALTHY NASAL EPITHELIAL CELLS}

doi:10.1136/thx.2010.150946.46

${ }^{1} \mathrm{D}$ Comer, ${ }^{1} \mathrm{~J} \mathrm{~S}$ Elborn, ${ }^{1} \mathrm{~V}$ Brown, ${ }^{2} \mathrm{C}$ McDowell, ${ }^{1} \mathrm{M}$ Ennis. ${ }^{1}$ Respiratory Medicine Group, Centre for Infection and Immunity, Queens University Belfast, Belfast, Northern Ireland; ${ }^{2}$ Clinical Research Support Centre, Belfast, Northern Ireland

Although cigarette smoke extract (CSE) is widely used in respiratory research, the methods used in its preparation are diverse and there is no consensus as to whether cigarette smoke extract (CSE) induces a pro-inflammatory or an immunosuppressive response in epithelial cells. ${ }^{1}$ Although the adverse effect that cigarette smoke has on the lower airway has been extensively studied, the responses of the nasal epithelium are not well described. Our aims were to study the effects of a non-cytotoxic CSE exposure on LPS-induced innate immune responses from primary nasal epithelial cells (PNECs), to assess the constitutive gene expression and the localisation of TLR-4 in PNECs by RT-PCR and flow cytometry, and finally to analyse the modulation of TLR-4 expression after stimulation PNECs by LPS \pm CSE pretreatment. CSE was prepared by combusting 1 or $212 \mathrm{mg}$ tar Marlboro cigarettes through $25 \mathrm{ml}$ of media. Submerged PNEC cultures were treated with CSE (or vehicle) followed by stimulation with LPS. Supernatants were assessed for IL- 8 and IL- 6 and the expression and localisation of TLR-4 was established. Cell viability was not affected except after $24 \mathrm{~h}$ incubation with 5\% CSE made from two cigarettes, or using single cigarette along with a $24 \mathrm{~h}$ stimulation with 20-25 $\mu \mathrm{g} / \mathrm{ml}$ LPS. A brief incubation with CSE (4 h) significantly inhibited LPS-induced cytokine release. In contrast, a more prolonged incubation with CSE (24 h) heightened LPS-induced cytokine release. Incubation with CSE ( $4 \mathrm{~h}$ and $24 \mathrm{~h}$ ) had no significant impact on expression of TLR4 mRNA. A brief incubation with CSE $(4 \mathrm{~h})$ resulted in a lower percentage of surface and intracellular TLR4. A prolonged incubation with CSE $(24 \mathrm{~h})$ did not affect surface or intracellular TLR4. CSE exposure for $4 \mathrm{~h}$ suppresses the inflammatory response in PNECs to stimulation with LPS whereas $24 \mathrm{~h}$ CSE exposure was pro-inflammatory. A reduced surface TLR-4 may account for the immunosuppressive effects, but unaltered surface and intracellular TLR-4 after $24 \mathrm{~h}$ CSE treatment suggests that alternative pathways may be responsible for the pro-inflammatory effects.

\section{REFERENCE}

1. Smith LA, et al. Inflammatory response of lung macrophages and epithelial cells to tobacco smoke: a literature review of ex vivo investigations. Immunol Res 2010;46:94-126.

\section{S146 MICROVASCULAR ENDOTHELIAL CELL APOPTOSIS AND DYSREGULATION OF VASCULAR ENDOTHELIAL GROWTH FACTOR RECEPTOR 2 (VEGF-R2) IN RESPONSE TO CIGARETTE SMOKE. NEW INSIGHTS INTO THE PATHOGENESIS OF EMPHYSEMA}

doi:10.1136/thx.2010.150946.47

${ }^{1} \mathrm{~L}$ S Mackay, ${ }^{2} \mathrm{~S}$ Dodd, ${ }^{2} \mathrm{~W}$ Tomlinson, ${ }^{2} \mathrm{D}$ Dougall, ${ }^{1} \mathrm{H}$ Walden, ${ }^{2} \mathrm{~B}$ Isherwood, ${ }^{1} \mathrm{~A}$ Gardner, ${ }^{1} \mathrm{~L}$ Borthwick, ${ }^{2} \mathrm{~K}$ Pinnion Brown, ${ }^{2} \mathrm{M}$ Foster, ${ }^{1} \mathrm{~A}$ J Fisher, ${ }^{1} \mathrm{P}$ A Corris ${ }^{1}$ Institute of Cellular Medicine, Newcastle University, Newcastle upon Tyne, UK; ${ }^{2}$ Astrazeneca $R+D$ Charnwood, Loughborough, UK

Microvascular injury may be a primary mechanism in the pathogenesis of emphysema. Rats treated with a VEGF-R2 antagonist develop emphysema that is caspase- 3 dependent. Additionally, patients with emphysema have reduced VEGF. We hypothesised that cigarette smoke injury may disrupt homeostatic vascular repair mechanisms and investigated VEGF-R2 expression and endothelial apoptosis in the pulmonary microvasculature of patients with emphysema.

Methods Microvascular endothelial cells were isolated from explanted peripheral lung tissue from four patients with emphysema undergoing transplantation. Cells were characterised via flow cytometry and confocal microscopy. Concurrent immunolocalisation of CD31, VEGF, VEGF-R2 and caspase-3 was performed on peripheral lung tissue from each patient and expression compared with that in excess normal lung tissue obtained from lobectomies. Isolated endothelial cells were treated with freshly prepared cigarette smoke extract (CSE) (3\%) for 0, 24, 48, $72 \mathrm{~h}$ and expression of VEGF$\mathrm{R} 2$ investigated via q-PCR. A cell permeable caspase-3 substrate, NucView 488 (Biotium), which is cleaved by the enzyme to form a high-affinity fluorescent DNA binding dye, was used to detect apoptosis via live cell imaging in response to CSE (0-12\%) over $64 \mathrm{~h}$. Results Isolated cells at low passage (P3-P6) expressed high levels of CD31, negligible CD90 and inducible CD62 confirming them as microvascular endothelial cells. VEGF-R2 expression was significantly reduced $(68 \% ; n=4, p<0.01)$ following treatment with 3\% CSE at $48 \mathrm{~h}$, compared with unstimulated cells. Live cell imaging demonstrated that cells underwent apoptosis in response to low dose CSE $(3 \%, 1 \mathrm{~h}$ treatment $)$ at $24 \mathrm{~h}(\mathrm{p}=0.05)$ compared with unstimulated cells. Immunohistochemical analysis revealed reduced CD31 expression in the alveolar bed of emphysema tissue, indicating capillary loss. Regional alveolar expression of VEGF-R2 was also reduced compared with non-emphysematous tissue. Caspase- 3 staining revealed positive cells in the alveolar bed, a sub-population of these indicating the presence of apoptotic endothelial cells in severe emphysema.

Conclusions Microvascular endothelial cells isolated from individuals with emphysema undergo accelerated apoptosis and down-regulate VEGF-R2 in response to CSE. These findings were consistent with the immunohistochemical analysis of emphysema tissue. This may represent a maladaptive response to CSE injury in susceptible individuals and be important in the pathogenesis of emphysema.

\section{S147 DIESEL EXHAUST PARTICLES ALTER MONOCYTE DIFFERENTIATION IN VITRO BUT HAVE LITTLE IMPACT ON NEUTROPHIL FUNCTION}

doi:10.1136/thx.2010.150946.48

${ }^{1} \mathrm{H}$ Jary, ${ }^{2} \mathrm{~K}$ Piddock, ${ }^{3} \mathrm{~K}$ Donaldson, ${ }^{2} \mathrm{~L}$ R Prince, ${ }^{2} \mathrm{~L} \mathrm{C}$ Parker, ${ }^{2} \mathrm{I}$ Sabroe, ${ }^{2} \mathrm{~N}$ Chaudhuri. ${ }^{1}$ Academic Unit of Respiratory Medicine, University of Newcastle, Newcastle, UK; 